\title{
e-Governance Implementation In Ebonyi State Nigeria: Challenges and Prospects
}

\author{
Fergus U. Onu \\ Department of Computer Science, \\ Ebonyi State University, Abakaliki - Nigeria.
}

\begin{abstract}
The deployment of Information and Communication Technology (ICT) in different facets of the world's economy has yielded very reasonable results. ICT has blured the barriers of hinderances in tourism, trade, healthcare, education and training. In governance and administration, ICT applications have enhanced the delivery of public services to citizens and clients not only by improving the process and management of government, but also by redefining the traditional concepts of citizenship. This paper examined the challenges facing the implementation of e-Governance in Ebonyi State - Nigeria and highlights the prospects. The research used a primary source of data by distributing, collecting and analysing a total of 500 questionnaires administered to respondents in the research area (Ebonyi State). The research found that the most difficult challenges facing the deployment of e-governance in Ebonyi State were lack of steady power supply, poor communication infrastructure and high cost of computer and internet equipments. The survey also revealed that the use of e-governance would bring improved efficiency in government operations without necessarily increasing the cost of state governance. e-Governance would strengthen democratic principles and ideologies which inturn brings good governance to the people.
\end{abstract}

Keywords: ICT, e-governance, good governance, internet, service delivery

\section{INTRODUCTION}

The purpose of governance in any society or organisation is to ensure optimal benefits of resources management to the stateholders. In Nigeria, the constitution (the 1999 constitution) identified three tiers of government namely; federal, state and local governments. Each of these tiers of has defined functions they render to the citizenry. Since the emergence of civil democracy in 1999, the states in Nigeria had better autonomy because the state governors were elected by the people as against the usual appointment by the president. This brought into the scene a set of politicians with a strong private sector background, who were determined to make their marks by results rather than patronage. If this pursuit will succeed, there must be a platform to enable the citizenry to participate in governmental decision making process; a platform where everyone will be given equal opportunities to express their views about government policies and programmes without the fear of being victimized.

The use of Information and Communication Technology (ICT) in different facets of the economy has yielded unquatifiable results. ICT has blured the barriers of hinderances in tourism, trade, education and training, etc. In the realm of government, ICT applications are promising to enhance the delivery of public goods and services to citizens not only by improving the process and management of government, but also by redefining the traditional concepts of citizenship and democracy.

The use of ICTs in governance is actually a means to improve the process of governance. The framework of e-governance, enables the partial automation of the major state functions and sectors to facilitate the optimal performance and better interaction of institutions attached to these sectors of the state. In fact
ICTs allows better interaction between the government, its institutions and the people.

To show that ICT is a necessity in governance, one must first consider whether the provision of the basic services are basic to the survival of the community. Basic services are "those activities that lead to the satisfaction of 'basic needs'. According to [1], basic needs range from the "minimum physiological needs" to a set or package that cover the following needs:

(a) basic necessities of life, such as food, water, clothing, fuel;

(b) needs which enhance the general welfare of the people;

(c) improve access to the means of production and economic opportunities, such as natural resources, capital (including technology), employment opportunities and income; and

(d) sense of security and freedom for decision making, such as human rights, political participation, social security, social defense and rule of law.

Based on this characterization of basic needs, ICTs can be viewed as instruments that help enable people to satisfy their basic needs. The idea that societies have survived over time even without ICT and thus need not change seems to forget the fact that societies, like all organizations, exist in an environment that is constantly changing. While ICT may not be in the category of basic needs directly, the role of ICT in development cannot be overemphasized. ICT bridges the information divide which determines the value societies place on these basic 
needs. [2] said that an information society requires information age governance and citizens. ICT brings greater effectiveness and transparency in government, while creating market opportunities for goods and services.

Access to ICT can expand opportunities. This idea is based on the fact that people and organizations deal with information in all of their daily activities. All organizations handle, deliver and process information in making decisions, developing plans, giving orders, and informing other people. Oral and written communication flows between people and organizations. It could be transmitted through the phone, fax machine, computers, or through the "grapevine". There will be greater efficiency, better decisions, and more effective use of resources if more accurate and reliable information can be sent more rapidly to the people who need them. This is exactly what ICT offers. When people have access to ICT, they have expanded choices to make instead of allowing others to make those choices for them.

Consequently, we can correctly say that ICT is a conduit channel for delivering basic services like healthcare and education to the people. ICT can help maintain and build social capital by keeping people in contact and by creating networks of individuals with the same interests. It serves as a means for transferring different resources, both financial and knowledge based. It is also dramatically less expensive, less time consuming and less dangerous than the physical transportation of people and documents/information. Groups who anticipate these benefits want countries to adopt appropriate policies to take advantage of these opportunities. They envision that rapid advances in ICTs could be the answer to bridging the gap between the rich and poor and hence deliver good governance to the people.

Solutions to development issues often require changes to government processes, e.g. by decentralization of government functions. Objectives are generally to improve efficiency and effectiveness and to save costs. The driving force can also be public demand for online services and information that increase democratic participation, accountability, transparency, and the quality and speed of services. The implementation and use of ICT solutions can support governance reforms. E-governance has become more and more present around the world in this decade. Internationally, most countries are in the early stages of e-governance implementation. A good progress has been made in Europe, USA and in other Westernized countries such as Australia and Singapore. In the recent years, developing countries and their citizens have joined others to benefit from e-governance.

In the words of [3], a situation in which all interaction with the government can be done through one counter 24 hours a day, 7 days a week, without waiting in lines at government offices is possible even now if governments are willing to decentralize responsibilities and processes through the use of electronic means such as the Internet. Each citizen can then make contact with the government through a portal where all forms, legislation, news and other information will be available. Of course, at first the front office will retain several communication channels, such as physical counters, telephone, e-mail and Internet to serve everyone properly. Commercial banks in Europe, the USA, Africa and Asia have adopted this concept. Most banking transactions are now done at an ATM, by mail or through the Internet. Only in a few very special situations one has to go to a physical counter to carryout a transaction. This has saved banks an enormous amount of costs. In other words, they do more work, with less people, in less time and with less and smaller offices. Government, as a collector and source of information, can also follow this trend, in order to serve its customers (citizens, businesses, and other interest groups) better and to save costs by making internal operations more efficient.

\section{GOVERNANCE AND E-GOVERNANCE DEFINED}

e-governance (Electronic governance) is a combination of the words electronic and governance. In this era of information revolution, every sphere of human activity has been revolutionized by electronic appliances in different machines especially the computer. Electronics in this context includes all devices like radio sets, television, telephones, computers, Global System of Mobile Communication (GSM) phones, the Internet, etc.

"Governance" has been defined by various authorities in though different, but related ways. [4] viewed governance as the exercise of economic, political and administrative authority to manage a country's affairs at all levels. It is about the process by which government, the private sector, citizens and groups articulate their interests, mediate their differences, and exercise their legal rights and obligations. [5] defined governance as the exercise of political, economic and administrative authority in the management of a country's affairs, including citizens' articulation of their interests and exercise of their legal rights and obligations. The World Bank in 1997 identified governance as having three distinct aspects thus: (1). the form of political regime; (2). the process by which authority is exercised in the management of a country's economic and social resources for development; (3). the capacity of governments to design, formulate and implement policies and discharge functions.

[6] wrote that the concept of governance denotes the use of political authority and exercise of control in a society in relation to the management of its resources for social and economic development. In the opinion of [7], governance comprises the institutions, processes and conventions in a society which determine how power is exercised, how important decisions affecting society are made and how various interests are accorded a place in such decisions. [8] defines it as the sum of the many ways individuals and institutions, public and private, manage their common affairs. It is a continuing process through which conflicting or diverse interests may be accommodated and co-operative action 
may be taken. It includes formal institutions and regimes empowered to enforce compliance, as well as informal arrangements that people and institutions either have agreed or perceive to be in their interest.

From the preceding study of the different definitions by leading institutions, governance is a term by which power is exercised. It is now clear that the concept of governance denotes a "participatory process".

[9], [10], [11] in their different opinions said that e-governance refers to the processes for ensuring egovernment. According to [5] e-governance is "the public sector's use of ICTs with the aim of:

1. improving information and service delivery,

2. encouraging citizen participation in the decision making process and

3. making government more accountable, transparent and effective".

The African training and research centre in administration for development (CAFRAD) defines egovernance as "the use of ICTs, and especially the Internet, to adopt a new conception and attitude of governance and management where participation and efficiency are required of all the stakeholders linked in a network"[12]. The definition presents e-governance as a new way of co-coordinating, planning, formulating and implementing decisions and operations related to governance problems. It can be used by governments "to re-invent themselves, get closer to the citizenry and forge closer alliances and partnerships with diverse communities of interest, practice, expertise, conviction and interdependence within the context of national and international development agenda" [12].

In this paper, we adopt e-governance as the application of information and communication technologies (ICTs) in

1. the delivery of government products and services, exchange of information, communication, transactions and system integration between government and citizens and government and businesses,

2. in the internal government operations to simplify and improve democratic, government and business aspects of Governance.

In this sense, the "e" in e-governance means/points to all of the following:

- $\quad$ efficiency in government transaction costs by using ICT to streamline their procedures, making their operations more efficient, better organised and more economical.

- effectiveness: ICT can help governments to achieve better results, meet development goals through increased participation, improve the process of resource allocation, respond timely to citizens' needs and increase coverage and quality of government services.

- empowerment: ICT can support increased interaction between citizens and their governments, for citizens both to participate in the decision making process and to become more aware of their personal and community development.

- economic and social development: Beyond the economic benefits that accrue to government due to efficiency and effectiveness gains, the use of ICTs in government and in its interaction

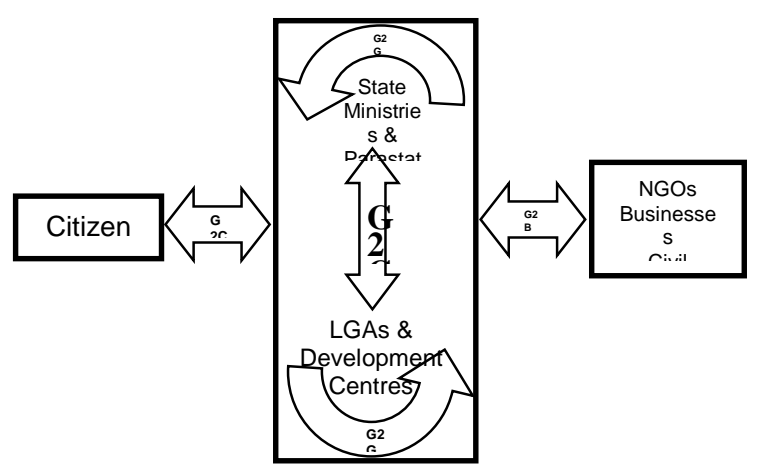

Fig. 1: Main groups interacting in e-governance

with the business community and citizens can create new businesses, attract investments and generate employment.

\section{E-GOVERNANCE AND GOOD GOVERNANCE}

Good governance rests on the pillars of knowledge and recognition of this set of knowledge by the decision makers and the people alike. Good governance is the desire of all citizens. Digitization of this entire set of knowledge within a network which is open to all individuals opens up possibilities for all to access and use the knowledge. The Introduction of eGovernance ensures that citizens can participate in, and influence decision-making processes which affect them closely. Citizens no longer remain passive recipients of governance services provided to them, but can proactively decide the types and standards of governance services they want and the governance structures which can best deliver them. ICTs can influence governance processes technically, supportively and innovatively.

The strategic objective of e-governance is to support and simplify governance for all the stakeholders which include: government, citizens and businesses. The use of ICT can connect all three parties and support processes and activities. In other words, e-governance uses electronic means to support and stimulate good governance. Therefore the objectives of e-governance are similar to the objectives of good governance. Good governance can be seen as an exercise of economic, political, and administrative authorities to better manage the affairs of a country at all levels, national and local. While governance is a neutral concept, good governance addresses the allocation and management of resources to respond to collective needs. Though a universally agreed position on what constitutes good governance may be hard to come by, conceptually, it is characterised by the 
principles of participation, transparency, accountability, rule of law, effectiveness, equity and strategic vision [4].

Good governance systems are participatory because they are based on democratic principles where the stakeholders in governance have a voice in the decision making process. Also the procedures and methods of decision making reflect transparency in order to ensure effective participation. The good governance system aims at "improving economic efficiency, protection and restoration of the environment and enhancing the wellbeing of the people" (adapted from International Institute of Sustainable Development, 1995). For [12], the idea of adopting ICTs in governance is to move government beyond passive informationgiving to active citizen involvement in the decision making process and this is what good governance is all about. Therefore e-governance has the potentials to bring about good governance.

\section{The Concept of e-Governance in State Administration}

The concept of e-governance is closely related to that of e-commerce. E-governance emerged in an attempt to translating the gains made in business through e-commerce into state government administration. From the definitions given above, the three main distinct groups interacting in e-governance concepts are government, citizens and businesses/interest groups. Abbreviations used in e-commerce such as B2B (business to business) and B2C (business to consumer) are used in e-governance to shortly describe which of the main groups are interacting. The most common group interactions in e-governance are G2C (Government to Citizen), G2B (Government to Business) and G2G (Government to Government). The interaction between the following groups in state governance is presented schematically in figure 1.

\section{Methodology}

In this paper, we used questionnaires as the instrument to collect data from primary source. We distributed a total of 500 questionnaires. 479 (i.e. $95.80 \%)$ were returned with responses while $7(1.4 \%)$ were either not returned or returned with invalid responses. Those were therefore discarded. The questionnaire was designed to assess the readiness of the stakeholders for the adoption of e-governance strategies for state administration in Ebonyi State. Table 1 shows the representation of the questionnaire administration. We addressed various aspects of e-governance in the questionnaire.

\section{RESULTS PRESENTATION}

Survey coverage: The questionnaire was distributed to both indegenes and none indegenes resident in the three senatorial zones of the state at the time of the survey. The coverage of the state in the distribution of the questionnaire is shown in figure 2 .

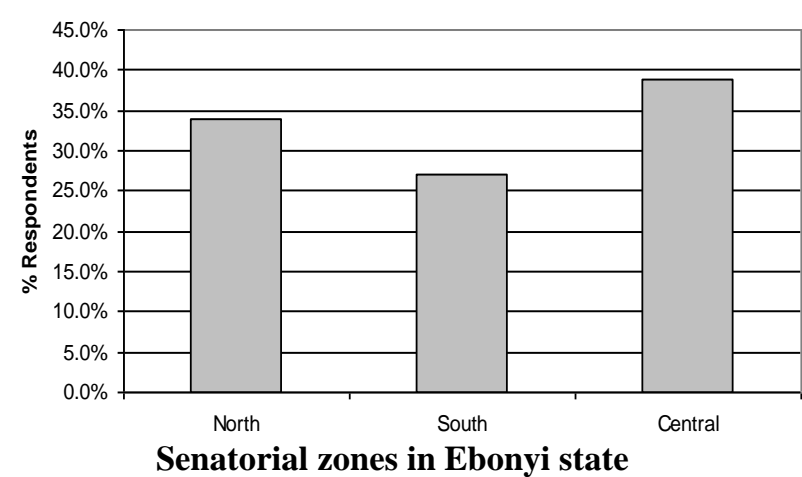

Fig. 2: Area covered in the questionnaires distribution

Age Distribution of Respondents: The age spread of the respondents that participated in the survey is shown in the pie chart of figure 3 . An interesting observation was from the survey showed that greater number $68 \%$ (i.e. for ages between $20-55$ as shown in pie chart) of the respondents earn some kind of salary, reside in other towns different from their home towns where there is computer business centres and as well have minimum qualifications of senior school certificate. Few respondents (15\%) are below the age of 20 years and are either secondary school levers or students.

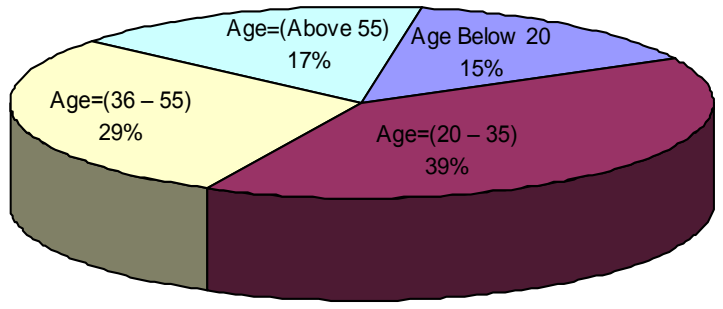

Fig. 3: Age Distribution of respondents

Possession of computer/IT skills is an important factor in e-governance implementation. When asked whether they know how to operate computer, figure 4 shows that $56.4 \%$ of the respondents said "yes", $32.2 \%$ said "just a little" while only $11.5 \%$ answered "no". Of the number that has the skill, they acquired the knowledge through private training personally funded by them or their guardians.

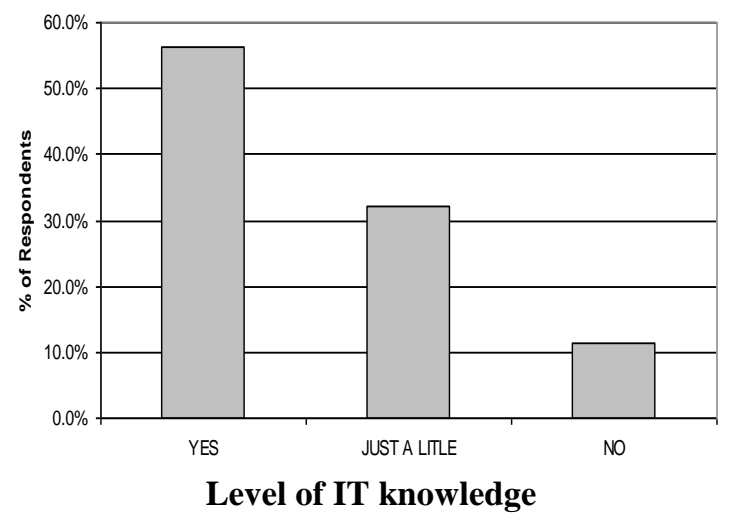

Fig. 4: Possession of computer/IT skills among respondents 
Considering the frequency at which respondents use Internet services, figure 5 shows that greater number of the respondents $58.2 \%$ use Internet/Online services very often, $25.1 \%$ use it rarely (not often) while $16.7 \%$ do not use it at all.
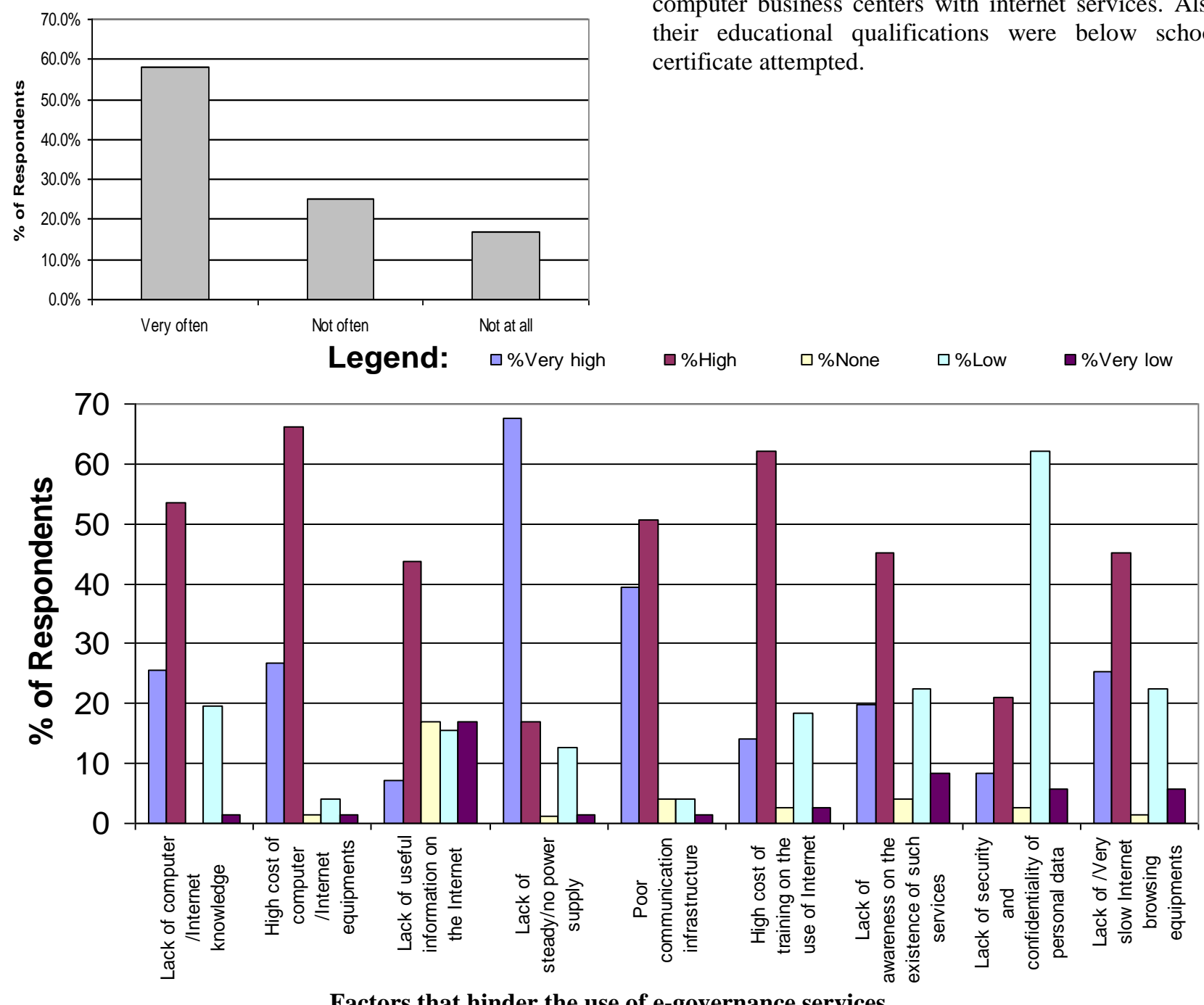

Factors that hinder the use of e-governance services

Fig. 6: Factors affecting the use of e-governance services in Ebonyi State.
Figure 6 is a chart of the opinions of respondents regarding the factors that hinder the use of e-governance services in Ebonyi State. These responses were studied and measured on a 5-point likert-type rating scale. The arithmetic mean of the responses were calculated to determine their levels and presented in table 1 . The result showed that the most pronounced challenges to the implementation of e-governance in Ebonyi State were:

1. lack of steady or no power supply with a calculated mean of $\chi=4.37$,

2. poor communication infrastructure with a calculated mean of $\chi=4.23$,

3. high cost of computer/internet equipments with a calculated mean of $\chi=4.13$.

\section{Frequency of use of IT}

Fig. 5: Frequency of usage of internet/online services

The respondents that do not use it at all were mainly respondents from the villages that do not have computer business centers with internet services. Also their educational qualifications were below school certificate attempted.
4. Lack of computer/internet knowledge with a calculated mean of $\chi=3.82$,

5. high cost of training on the use of internet with a calculated mean of $\chi=3.67$,

6. lack of /very slow internet browsing equipments with a calculated mean of $\chi=3.62$ and

7. lack of awareness on the existence of such services $(\chi=3.46)$ were next strong hindrances.

The other factors considered namely: Lack of useful information on the internet with arithmetic mean of $\chi=3.09$ and lack of security and confidentiality of personal data $(\chi=2.64)$ were low in the likert-type scale which shows that the respondents were of the opinion that the two factors were not strong hindrances to the use of e-governance services in the sampled communities.

Table 1: Analysis of responses on the factors that hinder the use of e-governance services in Ebonyi State 


\begin{tabular}{|c|c|c|c|c|c|c|}
\hline \multicolumn{2}{|c|}{ Factors } & \multirow[t]{2}{*}{$x$} & \multirow[t]{2}{*}{$f$} & \multirow[t]{2}{*}{$f \times$} & \multirow[t]{2}{*}{$\chi$} & \multirow[t]{2}{*}{$\%$} \\
\hline a & Lack of computer /Internet knowledge & & & & & \\
\hline & Very high & 5 & 122 & 610 & 3.82 & 25 \\
\hline & High & 4 & 256 & 1024 & & 53 \\
\hline & None & 3 & 0 & 0 & & 0 \\
\hline & Low & 2 & 94 & 188 & & 20 \\
\hline & Very low & 1 & 7 & 7 & & 1 \\
\hline \multirow{6}{*}{$\mathrm{b}$} & High cost of computer /Internet equipments & & & & & \\
\hline & Very high & 5 & 128 & 640 & 4.13 & 27 \\
\hline & High & 4 & 317 & 1268 & & 66 \\
\hline & None & 3 & 7 & 21 & & 1 \\
\hline & Low & 2 & 20 & 40 & & 4 \\
\hline & Very low & 1 & 7 & 7 & & 1 \\
\hline \multirow[t]{6}{*}{$\mathrm{c}$} & Lack of useful information on the Internet & & & & & \\
\hline & Very high & 5 & 34 & 170 & 3.09 & 7 \\
\hline & High & 4 & 209 & 836 & & 44 \\
\hline & None & 3 & 81 & 243 & & 17 \\
\hline & Low & 2 & 74 & 148 & & 15 \\
\hline & Very low & 1 & 81 & 81 & & 17 \\
\hline \multirow[t]{6}{*}{$\mathrm{d}$} & Lack of steady/no power supply & & & & & \\
\hline & Very high & 5 & 324 & 1620 & 4.37 & 68 \\
\hline & High & 4 & 81 & 324 & & 17 \\
\hline & None & 3 & 6 & 18 & & 1 \\
\hline & Low & 2 & 61 & 122 & & 13 \\
\hline & Very low & 1 & 7 & 7 & & 1 \\
\hline \multirow[t]{6}{*}{ e } & Poor communication infrastructure & & & & & \\
\hline & Very high & 5 & 189 & 945 & & 39 \\
\hline & High & 4 & 243 & 972 & 4.23 & 51 \\
\hline & None & 3 & 20 & 60 & & 4 \\
\hline & Low & 2 & 20 & 40 & & 4 \\
\hline & Very low & 1 & 7 & 7 & & 1 \\
\hline \multirow[t]{6}{*}{$\mathrm{f}$} & High cost of training on the use of Internet & & & & & \\
\hline & Very high & 5 & 68 & 340 & 3.67 & 14 \\
\hline & High & 4 & 297 & 1188 & & 62 \\
\hline & None & 3 & 13 & 39 & & 3 \\
\hline & Low & 2 & 88 & 176 & & 18 \\
\hline & Very low & 1 & 13 & 13 & & 3 \\
\hline \multirow[t]{6}{*}{$\mathrm{g}$} & Lack of awareness on the existence of such services & & & & & \\
\hline & Very high & 5 & 95 & 475 & 3.46 & 20 \\
\hline & High & 4 & 216 & 864 & & 45 \\
\hline & None & 3 & 20 & 60 & & 4 \\
\hline & Low & 2 & 108 & 216 & & 23 \\
\hline & Very low & 1 & 40 & 40 & & 8 \\
\hline
\end{tabular}




\begin{tabular}{|c|c|c|c|c|c|c|}
\hline \multirow[t]{5}{*}{ 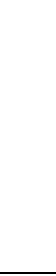 } & Very high & 5 & 40 & 200 & \multirow[t]{5}{*}{2.64} & 8 \\
\hline & High & 4 & 101 & 404 & & 21 \\
\hline & None & 3 & 13 & 39 & & 3 \\
\hline & Low & 2 & 298 & 596 & & 62 \\
\hline & Very low & 1 & 27 & 27 & & 6 \\
\hline \multirow[t]{6}{*}{ i } & Lack of /Very slow Internet browsing equipments & & & & & \\
\hline & Very high & 5 & 121 & 605 & \multirow[t]{5}{*}{3.62} & 25 \\
\hline & High & 4 & 216 & 864 & & 45 \\
\hline & None & 3 & 7 & 21 & & 1 \\
\hline & Low & 2 & 108 & 216 & & 23 \\
\hline & Very low & 1 & 27 & 27 & & 6 \\
\hline
\end{tabular}

\section{DISCUSSION}

The number of questionnaires distributed and returned with valid information were 479 i.e. $95.80 \%$ of the total number of questionnaires distributed. This number is a statistically acceptable size of the population for analysis. The distribution of the questionnaires was spread over the area considered for the survey in an acceptable proportion thus Ebonyi North (34\%), Ebonyi South (27\%) and Ebonyi Central (39\%). We observed and would want to report that $100 \%$ of the respondents owned at least a GSM phone and also have a phone call centre in their communities no matter how rural their community was. Other interesting findings include that $98 \%$ of the respondents were of the opinion that government services can be delivered to government clients namely: citizens, organizations and other government departments through GSM phones which incidentally forms the most common means of information communication now among the respondents. 98.8\% do not know whether Ebonyi State government has a functional website or not and $98.7 \%$ like to know about the activities of government functionaries.

\section{CONCLUSION}

The survey has shown that the most difficult challenges facing the deployment of e-governance in Ebonyi State were: lack of steady power supply, poor communication infrastructure and high cost of computer and internet equipments. The survey has also revealed that the use of e-governance would bring improved efficiency in government operations without necessarily increasing the cost of state administration. E-governance will induce accountability and prudence in the management of public fund. There will be easy access to information and government services, greater access to the people's representatives, greater participation of the people in the governance processes and hence egovernance strengthens democratic principles and ideologies. These are the real features of good governance.

So, the implementation of e-governance in Ebonyi State-Nigeria has very high prospects. There are truly some challenges, but the challenges are sur- mountable. Therefore, e-governance is a sure way of bringing good governance to the people.

\section{REFERENCES}

[1] Alampay E., Richard Heeks and Peter Paul A. Soliva (2003), Bridging the Information Divide: A Philippine Guidebook on ICTs for Development University of the Philippines, University of Manchester, Supported by AMIC, IDRC Canada and UNDP-APDIP online at http://www.apdip.net/elibrary (retrieved on September 26, 2008).

[2] Steven Clift (2002) E-Democracy: The Promise of the Future is a Reality Today online at http://www.publicus.net (retrieved on September 26, 2008).

[3] Michiel Backus (2001), E-Governance and Developing Countries Introduction and examples online @ www.iicd.org/about/publications/egovernanceand-develoing-countries-introductionandexamples/report3.pdf accessed september 25, 2009).

[4] UNDP APDIP (2007) Identifying 'Killer' eGovernance Applications for Telecentres Lessons from the Philippines online at http://www.apdip.net/apdipenote/21.pdf (accessed on September 24, 2008).

[5] UNESCO (2003); World Public Sector Report 2003: E-Government at the Crossroads New York

[6] Organisation for Economic Co-operation and Development (OECD) (1995), participatory development and good governance online @ www.oecd.org/dac/governancedevelopment/31857685.pdf retrieved September 24, 2012. 
International Journal of Computer Applications Technology and Research

Volume 4- Issue 11, 802 - 809, 2015, ISSN: 2319-8656

[7] Institute On Governance (2003) Principles for Good Governance in the $21^{\text {st }}$ Century Policy Brief No.15 online@

http://unpan1.un.org/intradoc/groups/public/do cuments/ UNPAN/UNPAN011842.pdf accessed on July 18, 2012.

[8] Commission on Global Governance (1995) Our Global Neighborhood report of the

Commission on Global Governance ISBN 019-827998-1; Published by Oxford University Press.

[9] Okot-Uma R. W. (2000), ELECTRONIC GOVERNANCE: Re-inventing Good
Governance London: Commonwealth Secretariat

[10] Holmes, D. (2001) eGov: eBusiness Strategies for Government. London, U.K.: Nicholas Brealey publishing.

[11] Tapscott, D. \& Caston, A. (1993). Paradigm Shift: The New Promise of Information Technology New York: McGraw-Hill

[12] Misuraca Ginluca (2007), e-governance in Africa from theory to action: a handbook on ICTs for local governance, IDRC-New Jersey, Africa World Press 